\title{
Effects of phosphorus on the growth and nitrogen fixation rates of Lyngbya majuscula: implications for management in Moreton Bay, Queensland
}

\author{
Ibrahim Elmetri ${ }^{1,2, *}$, Peter R. F. Bell ${ }^{1}$ \\ ${ }^{1}$ Division of Chemical Engineering, The University of Queensland, Brisbane, Queensland 4072, Australia \\ ${ }^{2}$ Present address: Institute of Technology and Engineering, Massey University, Turitea, New Zealand
}

\begin{abstract}
Significant acetylene reduction and therefore $\mathrm{N}_{2}$ fixation was observed for Lyngbya majuscula only during dark periods, which suggests that oxygenic photosynthesis and $\mathrm{N}_{2}$ fixation are incompatible processes for this species. Results from a series of batch and continuous-flow-culture reactor studies showed that the specific growth rate and $\mathrm{N}_{2}$ fixation rate of $L$. majuscula increased with phosphate $\left(\mathrm{P}^{-} \mathrm{PO}_{4}\right)$ concentration up to a maximum value and thereafter remained constant. The $\mathrm{P}_{-} \mathrm{PO}_{4}$ concentrations corresponding to the maximum $\mathrm{N}_{2}$ fixation and maximum growth rates were $\sim 0.27$ and $\sim 0.18 \mu \mathrm{M}$ respectively and these values are denoted as the saturation values for $\mathrm{N}_{2}$ fixation and growth respectively. Regular monitoring studies in Moreton Bay, Queensland, show that concentrations of $\mathrm{P}_{-} \mathrm{PO}_{4}$ generally exceed these saturation values over a large portion of the Bay and therefore, the growth of the bloom-forming $L$. majuscula is potentially maximised throughout much of the Bay by the elevated $\mathrm{P}_{-} \mathrm{PO}_{4}$ concentrations. Results from other studies suggest that the elevated $\mathrm{P}_{-} \mathrm{PO}_{4}$ concentrations in the Bay can be largely attributed to discharges from waste-water treatment plants (WWTPs), and thus it is proposed that the control of the growth of L. majuscula in Moreton Bay will require a significant reduction in the P load from the WWTP discharges. If the current strategy of $\mathrm{N}$ load reduction for these discharges is maintained in the absence of substantial P load reduction, it is hypothesised that the growth of L. majuscula and other diazotrophs in Moreton Bay will increase in the future.
\end{abstract}

KEY WORDS: Lyngbya majuscula Nitrogen fixation $\cdot$ Phosphorus $\cdot$ Continuous culture $\cdot$ Growth kinetics $\cdot$ Moreton Bay

\section{INTRODUCTION}

Extensive blooms of the cyanobacterium (blue-green alga) Lyngbya majuscula have recently been recorded in the Deception Bay region of northern Moreton Bay Queensland (see Fig. 1) and in other regions along the coast of Queensland (Dennison et al. 1999). The blooms in Deception Bay have had a major impact on the ecology, with associated fish and sea grass kills being recorded. Directly associated human health problems, namely respiratory problems and skin irritations have led to closure of beaches in Moreton Bay. A very extensive bloom of another cyanobacterium, Trichodesmium, occurred in Moreton Bay in November
2002; this also led to the closure of beaches. Such blooms of cyanobacteria appear to be on the increase in other regions along the coast of Queensland (Bell et al. 1999) and are affecting many coastal regions around the world (Zimmerman \& Montgomery 1984, Lapointe \& Clark 1992, Porter \& Meier 1992, Shannon et al. 1992, Lapointe et al. 1993, Sellner 1997, Nagle \& Paul 1998, Kuffner \& Paul 2001). The $\mathrm{N}_{2}$ fixing ability of these taxa suggests that nutrients other than nitrogen, e.g. phosphorus (P) and/or iron (Fe), are contributing to the occurrence of these blooms. $\mathrm{P}$ and $\mathrm{Fe}$ are required by all algae for the synthesis of various cell constituents, but $\mathrm{N}_{2}$-fixing cyanobacteria (diazotrophs) require additional amounts of these nutrients 




Fig. 1. The Moreton Bay region of SE Queensland, Australia showing locations of waste-water treatment plants (WWTPs), sites of significant Lyngbya majuscula growth (LMS 2003) and contours of mean $\mathrm{P}_{-} \mathrm{PO}_{4}$ concentrations (EHMP 2001)

for synthesis and activation of nitrogenase (Howarth et al. 1988, Paerl 1990). The 'new' $N$ fixed by the diazotrophs provides an important source of $\mathrm{N}$ for other alga taxa; it has been suggested that oceanic productivity depends, to a significant extent, on this 'new' $\mathrm{N}$ and therefore, the productivity in the oceanic regions as a whole could well be P-limited (Tyrrell 1999).

The genus Lyngbya is a widespread and often a dominant component of marine and freshwater microbial mats. Previous studies have shown that various marine and freshwater species of Lyngbya, including L. majuscula, fix $\mathrm{N}_{2}$ (Jones 1990, Paerl et al. 1991, Phlips et al. 1992, Dennison \& Abal 1999). Dennison et al. (1999) hypothesised that Fe was primarily responsible for L. majuscula blooms in Deception Bay. This hypothesis was based on a set of batch bioassays, which showed that Fe-EDTA stimulated the $\mathrm{N}_{2}$ fixation of L. majuscula. However, the same study showed that the addition of EDTA alone also stimulated the $\mathrm{N}_{2}$ fixation rate of L. majuscula, which suggests that it was the bioavailability of some trace component, not necessarily $\mathrm{Fe}$, that was limiting the $\mathrm{N}_{2}$ fixation in their samples. Dennison et al. (1999) recognise that P loading is often an important factor in controlling the growth of cyanobacteria in coastal ecosystems but suggested it was not an important factor in the Deception Bay region because the concentrations of $\mathrm{P}_{-} \mathrm{PO}_{4}$ were relatively low. However, it is noted that no studies to date have determined the relationship between the growth of L. majuscula and the concentrations of P$\mathrm{PO}_{4}$. The present study uses a series of batch and semicontinuous studies to investigate the importance of P$\mathrm{PO}_{4}$ in promoting the $\mathrm{N}_{2}$ fixation rate and growth rate of L. majuscula, and shows that the concentrations of $\mathrm{P}_{-} \mathrm{PO}_{4}$ throughout most of Moreton Bay are actually relatively high when compared with the P-requirements of L. majuscula.

It is generally accepted that the growth rate of algae is a function of intracellular $\mathrm{P}$ concentration and that this internal concentration is a function of the external $\mathrm{P}$ concentration. Therefore, an exact relationship between external $\mathrm{P}$ concentrations and growth rate during P-limited growth conditions is only determinable during steady-state growth situations, i.e. where the external- and hence the internal-cellular P concentrations remain constant (Fuhs 1969, Droop 1973, Goldman 1977). Such steady-state conditions cannot be achieved in batch cultures during nutrientlimited growth situations because the internal and external P concentrations are varying, and therefore chemostat type studies have been employed in some past studies on phytoplankton growth (Fuhs 1969, Goldman 1977). Practically though, such procedures are not useful for studying all algal taxa. For example, some taxa will not grow under continuous light conditions (e.g. Trichodesmium spp.) and others (e.g. macroalgae) will not readily mix and exit with the flow of medium. Both these aspects are relevant to the growth of Lyngbya majuscula. Firstly, it grows in the light but, as is discussed below, it fixes $\mathrm{N}_{2}$ mainly in the dark, and secondly, it grows as long continuous filaments that cannot easily mix and exit with the medium. Thus, continuous flow culture methods had to be devised that allowed the biomass to be retained and yet maintained a relatively constant external $\mathrm{P}_{-} \mathrm{PO}_{4}$ concentration throughout each experiment.

\section{MATERIALS AND METHODS}

All chemicals used in the study were analytical grade reagents. All glassware and pump tubing were acid-washed and thoroughly rinsed with Milli-Q water prior to use. Lyngbya majuscula Harvey ex Gomont was collected from a shallow region at the northern 
end of Deception Bay in February 2000 (Fig. 1) and cultured in a nitrogen-free artificial seawater medium based on the Aquil medium of Morel et al. (1979) containing $3 \mu \mathrm{M} \mathrm{P}-\mathrm{PO}_{4}$. For the purpose of this study, the culture was adapted and grown in an enriched seawater medium (ESW) (Table 1), because the salt solution used to make the Aquil medium was found to contain significant levels of soluble reactive phosphorus (i.e. P$\mathrm{PO}_{4}$ of $0.4 \mu \mathrm{M}$ ). The seawater was collected from the northern section of the outer Great Barrier Reef near to Agincourt Reef, in a deep channel away from the influence of the coral reefs; the seawater was pre-filtered through Millipore GF filters, filter-sterilised through $0.2 \mu \mathrm{m}$ sterile-filter and stored in $20 \mathrm{l}$ acid-washed containers. This seawater was analysed for $\mathrm{P}_{-} \mathrm{PO}_{4}$, ammonia and nitrate on a Lachat autoanalyser; all were found to be below the detection limits $(0.03 \mu \mathrm{MP}$ and $0.07 \mu \mathrm{MN}$ ). All media were filter-sterilised using $0.2 \mu \mathrm{m}$ sterile-filters and were stored at $4^{\circ} \mathrm{C}$ in a refrigerator. All media were again filter-sterilized prior to use. Examination of the cultures under 1000× magnification using normal light and epifluorescence microscopy (Hass 1982) demonstrated that the stock cultures were unialgal and that minimal, if any, bacterial growth occurred on the surface of the filaments or in the medium.

Growth experiments. The growth studies were investigated using batch and continuous cultures in $35 \mathrm{ml}$ glass Petri dishes $(10 \mathrm{~cm}$ diameter) fitted with glass tops. Filaments were selected from the stock culture and were cut to $3 \mathrm{~mm}$ lengths just prior to the start of each experiment. The growth conditions were maintained at an average laboratory temperature of $25^{\circ} \mathrm{C}$ and cultures were exposed to a $12 \mathrm{~h}$ light:12 h dark light cycle. Light irradiance (PAR) of $55 \mu \mathrm{mol}$ quanta $\mathrm{m}^{-2} \mathrm{~s}^{-1}$ was provided from a bank of cool fluorescent tubes above the culture vessels. Biomass was determined daily by measuring the length of the filaments $(\mathrm{mm})$ in the glass culture dishes under a stereomicro-

Table 1. Enriched seawater medium (ESW)

\begin{tabular}{|llc|}
\hline Nutrient & Chemical used & Concentration (M) \\
\hline $\mathrm{P}^{-\mathrm{PO}_{4}}$ & $\mathrm{KH}_{2} \mathrm{PO}_{4}$ & $3.00 \times 10^{-6}$ \\
Trace metal & $\mathrm{Fe}-\mathrm{EDTA}$ & $2.50 \times 10^{-7}$ \\
& $\mathrm{Na}_{2} \mathrm{H}_{2} \cdot \mathrm{EDTA} \cdot 2 \mathrm{H}_{2} \mathrm{O}$ & $4.5 \times 10^{-6}$ \\
& $\mathrm{CuSO}_{4} \cdot 5 \mathrm{H}_{2} \mathrm{O}$ & $9.97 \times 10^{-10}$ \\
& $\left(\mathrm{NH}_{4}\right)_{6} \mathrm{Mo}_{7} \mathrm{O}_{24} \cdot 4 \mathrm{H}_{2} \mathrm{O}$ & $1.50 \times 10^{-9}$ \\
& $\mathrm{CoCl}_{2} \cdot 6 \mathrm{H}_{2} \mathrm{O}$ & $2.50 \times 10^{-9}$ \\
& $\mathrm{MnCl}_{2} \cdot 4 \mathrm{H}_{2} \mathrm{O}$ & $2.30 \times 10^{-8}$ \\
& $\mathrm{ZnSO}_{4} \cdot 7 \mathrm{H}_{2} \mathrm{O}$ & $4.00 \times 10^{-9}$ \\
& $\mathrm{~B}_{12}$ & $3.62 \times 10^{-7}$ \\
& $\mathrm{Biotin}$ & $2.05 \times 10^{-6}$ \\
& Thiamine $\mathrm{HCl}$ & $2.88 \times 10^{-4}$ \\
\hline
\end{tabular}

scope. It is noted that the filaments are denser than the medium, and hence they sank and stayed on the bottom of the chamber even during the continuous flow studies. The measurements were conducted at the same time each day to provide accurate daily growth rate calculations. On occasion, some objectiveness was required in the measurement in order to take into account bending and tangles of filaments. Forceps were used to gently grip and straighten the filaments to facilitate the measurements.

In each batch experiment, one $3 \mathrm{~mm}$ filament of Lyngbya majuscula was placed in a culture dish with $25 \mathrm{ml}$ of the various ESW media. The ESW media were made up with a wide range of $\mathrm{P}^{-} \mathrm{PO}_{4}$ additions $(0,0.08$, $0.16,0.33,0.66,1,4 \mu \mathrm{M})$. Cultures were grown in triplicate for each treatment for up to $16 \mathrm{~d}$ and biomass was measured daily.

The continuous-flow culture (CFC) system consisted of a pump, tubing and the same type of culture dish used for the batch studies $(35 \mathrm{ml}$ glass Petri dish with glass cover). Two small holes were drilled, 1 on each side of the glass cover, to provide for the inlet and outlet tubing ( $3 \mathrm{~mm} \mathrm{OD;} 0.9 \mathrm{~mm}$ ID). Medium was pumped to and from each $\mathrm{CFC}$ reactor at the same flow-rate using multiple-head peristaltic pumps. The flow rates $\left(F, \mathrm{ml} \mathrm{h}^{-1}\right)$ were measured and calibrated using a $5 \mathrm{ml}$ measuring cylinder and a timer prior to the start of each experiment, and were monitored daily by measuring the outflow volume collected. The volume of liquid in each CFC reactor $(V, \mathrm{ml})$ was maintained constant at $25 \mathrm{ml}$; this was aided by placing the exit flow tube at a fixed height above the bottom of the $\mathrm{CFC}$ reactor. An initial series of experiments was carried out with a residence time $(\tau=V / F)$ of $\sim 2$ h, i.e. the reactor volume was changed every $2 \mathrm{~h}$ which is equivalent to a dilution rate $(D=24 \times F / V)$ of $\sim 12 \mathrm{~d}^{-1}$. It was noted that with the initial experiments the exit $\mathrm{P}-\mathrm{PO}_{4}$ concentration tended to drop by about $0.03 \mu \mathrm{M}$ after about $4 \mathrm{~d}$ growth, and therefore the flow rate was increased by about $10 \%$ every 4 to $5 \mathrm{~d}$ to counteract this. Mixing was aided by placing the inflow tube above the solution surface and the energy of the waves generated from the falling drops supplied significant mixing in the vessel. The ESW outflow (exit) samples were collected daily, filtered $(0.2 \mu \mathrm{m}$ filter pore size) and analysed for $\mathrm{P}_{-} \mathrm{PO}_{4}$ using the method of Parsons et al. (1984).

The CFC experiments were initiated by filling each culture vessel with $25 \mathrm{ml}$ of the various media containing the different $\mathrm{P}_{-} \mathrm{PO}_{4}$ concentrations. Four $3 \mathrm{~mm}$ filaments of Lyngbya majuscula were placed in each CFC reactor. Flow of medium was started immediately and maintained on a continuous basis over the entire culture period $(\sim 2 \mathrm{wk})$. In order to achieve a wide range of exit $\mathrm{P}-\mathrm{PO}_{4}$ concentrations, 8 inlet $\mathrm{P}-\mathrm{PO}_{4}$ concentrations 

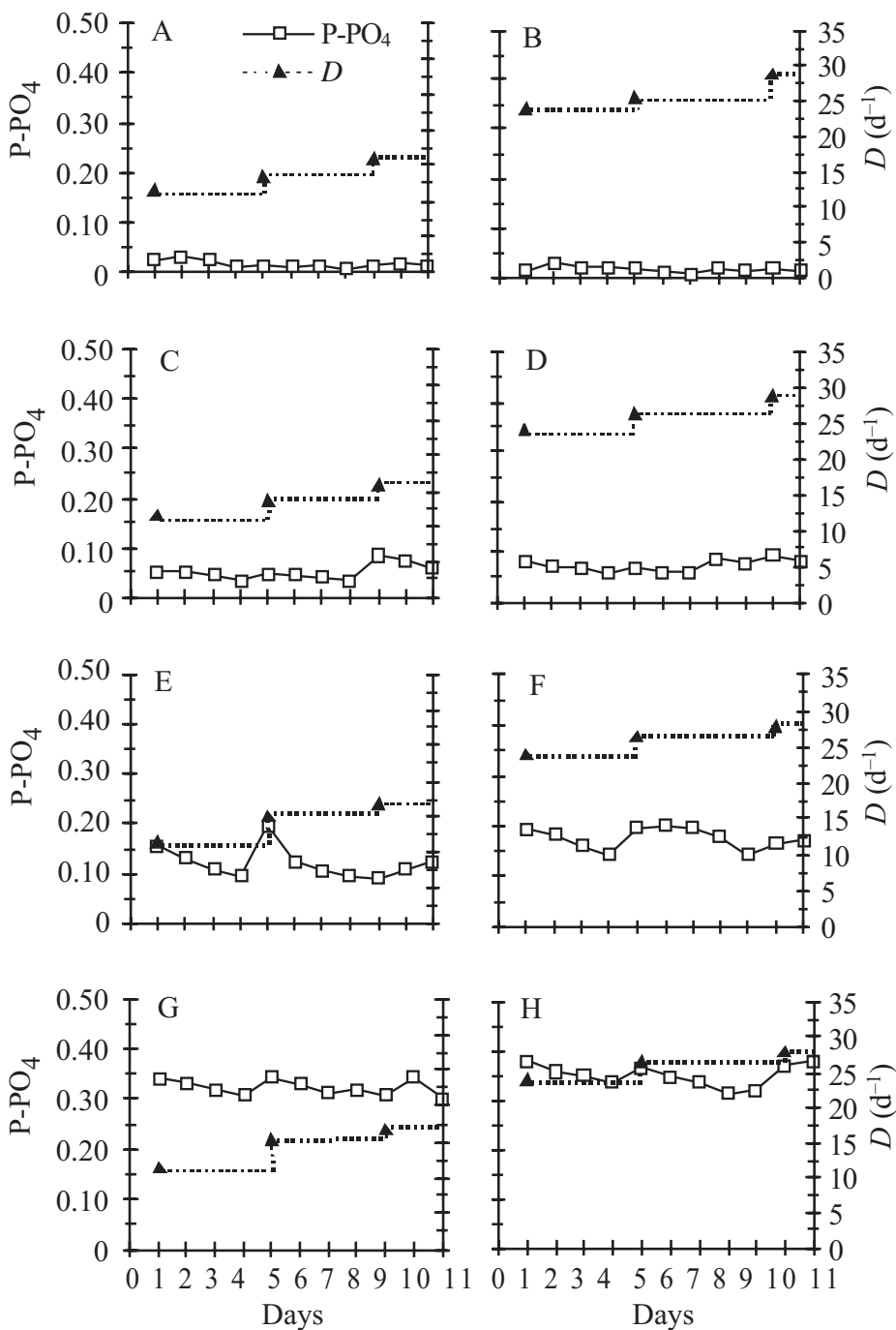

Fig. 2. Time course of $\mathrm{CFC}$ exit $\mathrm{P}-\mathrm{PO}_{4}$ concentrations $(\mu \mathrm{M})$. (A-H) represent the different $\mathrm{CFC}$ reactors with high and low dilution rates, $D\left(\mathrm{~d}^{-1}\right)$

in the range of 0.02 to $0.4 \mu \mathrm{M}$ were used in conjunction with a series of low-flow $\left(D \approx 12 \mathrm{~d}^{-1}\right)$ and high-flow ( $D$ $\sim 30 \mathrm{~d}^{-1}$ ) experiments. To demonstrate there was no loss of $\mathrm{P}_{-} \mathrm{PO}_{4}$ caused by other factors, a control CFC reactor containing no L. majuscula was run in parallel.

Each CFC experiment provided 1 value for the mean specific growth rate $(\mu)$ at 1 mean ambient concentration of $\mathrm{P}_{-} \mathrm{PO}_{4}$. In carrying out these calculations, the results for the first $5 \mathrm{~d}$ of each experiment were ignored in order to avoid any adaptation/nutrient storage effects. Thus, mean specific growth rates were determined during the 5 d growth period from Days 6 to 11 for each reactor. The success of the reactor set-up and operating procedures are well demonstrated by the achievement of essentially constant reactor exit $\mathrm{P}_{-} \mathrm{PO}_{4}$ concentrations for significant periods for all experiments (Fig. 2).
$\mathbf{N}_{2}$ fixation. Preliminary studies were conducted on the stock cultures to determine the effects of the light/dark cycle on the $\mathrm{N}_{2}$ fixation. Four actively growing samples were transferred to $15 \mathrm{ml}$ wide mouth serum bottles for determination of $\mathrm{N}_{2}$ fixation rates using the acetylene reduction method (Capone 1993). The filaments had been growing for $5 \mathrm{~d}$ on a $12 \mathrm{~h}$ light:12 h dark cycle. Samples were selected following an initial $3 \mathrm{~h}$ exposure to light. Each bottle was sealed with a long-skirted red-silicone rubber serum stopper. Acetylene gas, obtained from a cylinder, was injected into each bottle using a gas-tight syringe to give an initial gas phase concentration of at least $15 \%$. A $0.1 \mathrm{ml}$ gas phase sample was extracted from each bottle at zero time using a gas tight syringe and was analysed immediately for ethylene concentration using a Photovac 10s plus a portable gas chromatograph fitted with a photo ionisation detector. The sample bottles were incubated in the laboratory at $25 \pm 1.5^{\circ} \mathrm{C}$ for periods of $9 \mathrm{~h}$ in the light $\left(45 \mu \mathrm{mol}\right.$ quanta $\left.\mathrm{m}^{-2} \mathrm{~s}^{-1}\right)$ followed by $12 \mathrm{~h}$ in the dark. Gas samples $(0.1 \mathrm{ml})$ were taken periodically throughout the light/dark incubation period with a gas tight syringe and analysed for ethylene. The gas phases of several control blanks, i.e. bottles containing filtered medium with added acetylene but with no added Lyngbya majuscula, were also analysed at zero time and after the incubation period in order to determine the background ethylene concentration in the absence of any acetylene consumption by $L$. majuscula. The bottle contents were gently removed at the end of each experiment and the length $(\mathrm{mm})$ of the filaments was estimated under a stereotype microscope fitted with a scale. A molar conversion factor of 4:1 was assumed in converting the ethylene production rates to $\mathrm{N}_{2}$ fixation rates (Capone 1993).

The effect of various $\mathrm{P}-\mathrm{PO}_{4}$ concentrations on the $\mathrm{N}_{2}$ fixation rate was also investigated. The Lyngbya majuscula filaments used in this experimental work were removed from the stock cultures, cut into $10 \mathrm{~mm}$ lengths under a stereomicroscope and transferred to ESW containing no added $\mathrm{P}\left(\mathrm{P}_{-}-\mathrm{PO}_{4}<0.03 \mu \mathrm{M}\right)$ and incubated $\left(25 \pm 1.5^{\circ} \mathrm{C} ; 12 \mathrm{~h}\right.$ dark: $12 \mathrm{~h}$ light; 55 umol quanta $\mathrm{m}^{-2} \mathrm{~s}^{-1}$ ) for $3 \mathrm{~d}$ in order to starve the cells from the stored phosphorus. The phosphorus-deficient filaments were then transferred to $100 \mathrm{ml}$ flasks containing $50 \mathrm{ml}$ of medium containing various amounts of added $\mathrm{P}_{-} \mathrm{PO}_{4}: 0.1,0.2,0.33,0.67,1.0 \mu \mathrm{M}$. The cultures were grown for $2 \mathrm{~d}$ in order to establish a pseudosteady state equilibrium between the external P concentration and the cell P concentration. A 'zero'-control sample was also prepared by incubating filaments 
for $2 \mathrm{~d}$ in $\mathrm{ESW}$ with no added $\mathrm{P}-\mathrm{PO}_{4}$. After the incubation period, the filaments plus medium were transferred to $15 \mathrm{ml}$ wide mouth serum bottles for determination of dark-induced $\mathrm{N}_{2}$ fixation rates using the acetylene reduction method as described above. All experiments were done in duplicate. Light-induced $\mathrm{N}_{2}$ fixation was not investigated in this set of experiments because, as discussed below, the initial experiments had shown this to be minimal when compared with the dark-induced $\mathrm{N}_{2}$ fixation. Samples for $\mathrm{P}_{-} \mathrm{PO}_{4}$ analysis were collected from all cultures, filtered $(0.2 \mu \mathrm{m}$ pore size) and analysed using the method described in Parsons et al. (1984).

\section{RESULTS AND DISCUSSION}

\section{$\mathrm{N}_{2}$ fixation studies}

Only minimal acetylene reduction, and consequently $\mathrm{N}_{2}$ fixation, was observed during the light periods, which suggests that oxygenic photosynthesis and $\mathrm{N}_{2}$ fixation are incompatible processes for this species. These results confirm those of Lundgren et al. (2003), who found that natural populations of Lyngbya majuscula only fixed nitrogen during the dark phase of a diel cycle but do not agree with those of Jones (1990) and Dennison et al. (1999), who found that field-collected samples of $L$. majuscula exhibited nitrogenase activity only during the light phase. Paerl et al. (1991) found that $L$. aestuarii, which if one were to adopt the classification of Drouet (1968) is the same species as $L$. majuscula, exhibited nitrogenase activity in both the light and dark but the fixation in the dark was much greater than that exhibited in the light. The temporal separation of photosynthetic (light) and $\mathrm{N}_{2}$ fixation (dark) processes as suggested by our results has previously been observed for other non-heterocystous diazotrophs, e.g. Gloeothece sp. and Oscillatoria sp. (Stal \& Krumbein 1985). Stal \& Krumbein (1985) also showed that when the dark cycle is reduced to $4 \mathrm{~h}$, significant $\mathrm{N}_{2}$ fixation by Oscillatoria spp., which normally only occurs in the dark, also occurs in the light. Also, Phlips et al. (1992) showed that aerobic $\mathrm{N}_{2}$ fixation by $L$. wollei varies significantly with light intensity and with the duration of light:dark cycles. Thus, it is possible that the results of Jones (1990) and Dennison et al. (1999) for their field-collected samples are a reflection of the changed light/dark cycle conditions between the field and the laboratory. It is also possible that the field samples might have been contaminated with other bacteria/cyanobacteria although Jones (1990) suggests this is unlikely for his samples.

The dark-stimulated acetylene reduction rate, and consequently $\mathrm{N}_{2}$ fixation rate, increased linearly with
$\mathrm{P}-\mathrm{PO}_{4}$ concentration up to $0.27 \mu \mathrm{M}$ and then showed no further increase up to $0.85 \mu \mathrm{M}$ (Fig. 3). These findings are in general agreement with the work of Stewart \& Alexander (1971), which showed that the acetylene reduction rate for 3 freshwater diazotrophs was proportional to the $\mathrm{P}-\mathrm{PO}_{4}$ concentration up to approximately $0.6 \mu \mathrm{M}$ with no further increase beyond 1.6 $\mu \mathrm{M}$. Mague et al. (1974) also showed that increased $\mathrm{P}_{-} \mathrm{PO}_{4}$ concentrations stimulated acetylene reduction in samples containing the $\mathrm{N}_{2}$ fixing Richelia intracellularis, and Carpenter \& Price (1977) and Sañudo-Wilhelmy et al. (2001) found that higher cellular $\mathrm{N}_{2}$ fixation rates for Trichodesmium correlated with elevated $\mathrm{P}_{-} \mathrm{PO}_{4}$ concentrations. In physiological terms, $\mathrm{N}_{2}$ fixation is a very energetically demanding process, requiring between 12 and 16 molecules of ATP for the reduction of 1 molecule of $\mathrm{N}_{2}$ (Postgate 1982) and thus, the strong dependence of $\mathrm{N}_{2}$ fixation on the concentration of $\mathrm{P}-\mathrm{PO}_{4}$ is not surprising.

\section{Batch growth studies}

Results from the batch studies (Fig. 4) show the final biomass achieved is dependent on the initial $\mathrm{P}-\mathrm{PO}_{4}$ concentration, i.e. the system is P-limited. The results also show that the initial growth rates for all treatments including the 'zero'-control medium were essentially the same over the first 3 to $4 \mathrm{~d}$, suggesting that a 3 to $4 \mathrm{~d}$ lag period is required for this diazotroph to adapt to the new environment. It is noted that the initial growth during this period would be largely driven by the initial cellular P content, which would be essentially the same for all cultures. The results for the higher concentration media $(\geq 0.33 \mu \mathrm{M})$ are quite similar for the first $10 \mathrm{~d}$ of growth, while there is a definite drop-off in growth during that period for the cultures in media with lower initial concentrations of $\mathrm{P}_{-} \mathrm{PO}_{4}$. As noted

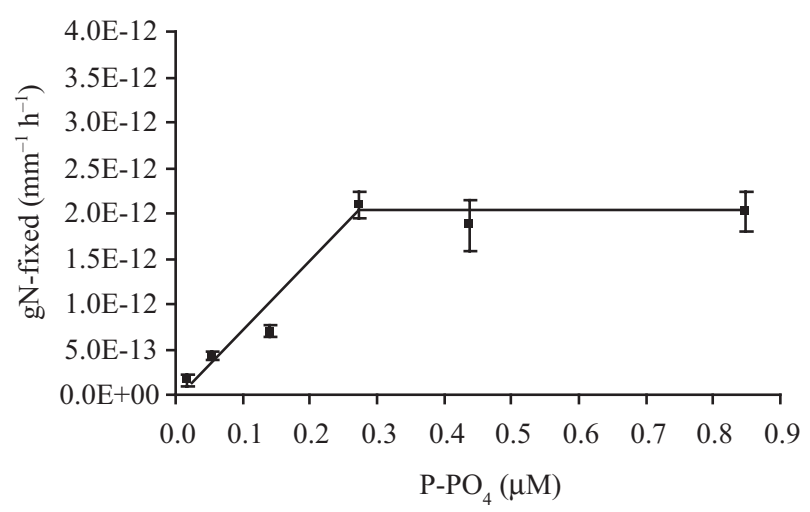

Fig. 3. Lyngbya majuscula. Mean nitrogen fixation rates for different $\mathrm{P}-\mathrm{PO}_{4}$ concentrations. Error bars denote SD 


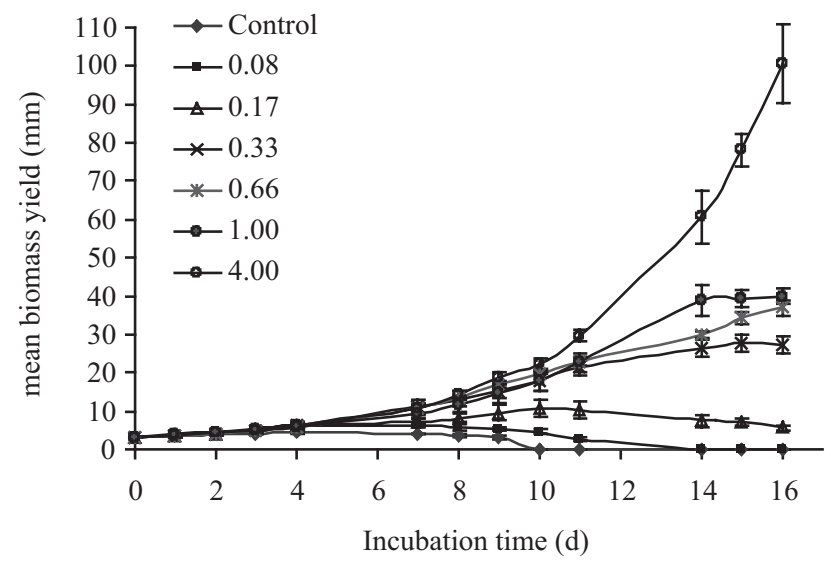

Fig. 4. Lyngbya majuscula. Effect of $\mathrm{P}^{-} \mathrm{PO}_{4}$ concentrations on growth in batch culture studies. Legend shows $\mathrm{P}_{-} \mathrm{PO}_{4}$ concentration in $\mu \mathrm{M}$. Error bars denote SD

above, the concentration of $\mathrm{P}_{-} \mathrm{PO}_{4}$ would be varying with time in these batch cultures, and therefore it is not possible to determine the direct relationship between external $\mathrm{P}$ concentrations and growth rate from such experiments. Overall, such batch studies can provide useful information on the nutrient uptake kinetics from pulsed inputs and the status of nutrient limitation, but provide little useful information on the effects of low levels of limiting nutrients on growth rates.

\section{Continuous flow culture studies}

The results from the continuous growth studies (Fig. 5) show that the growth rate increases with $\mathrm{P}_{-} \mathrm{PO}_{4}$ concentration up to about $0.18 \mu \mathrm{M}$, beyond which a plateau is reached at $\sim 0.33 \mathrm{~d}^{-1}$. This result is similar to that obtained for the relationship between $\mathrm{N}_{2}$ fixation

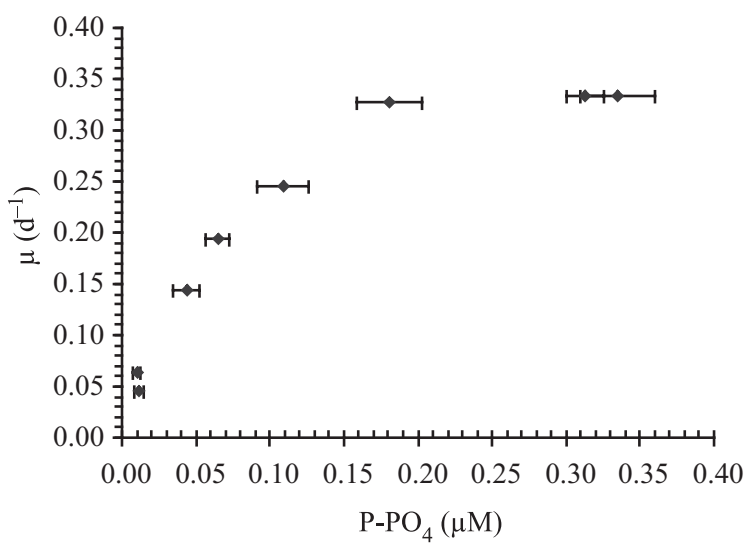

Fig. 5. Lyngbya majuscula. Effect of $\mathrm{P}_{-} \mathrm{PO}_{4}$ concentration on specific growth rate, $\mu\left(\mathrm{d}^{-1}\right)$ in continuous flow culture (CFC) studies. Error bars denote SD rate and $\mathrm{P}_{-} \mathrm{PO}_{4}$ concentration suggesting that the $\mathrm{N}_{2}$ fixation rate could play an important role in controlling the growth rate. Various formulations have been used in the past for describing the relationship between phytoplankton productivity or growth rate and the concentration of $\mathrm{P}_{-} \mathrm{PO}_{4}$ in a P-limited system. Many workers have assumed a Monod type relationship (Tyrrell 1999) but the formation of the plateau suggests such a relationship would not be appropriate for our data. Early modelling studies on phosphorus-limited growth of phytoplankton in the marine environment (Steele 1958, Riley 1963) assumed that below a limiting or saturation concentration $\left(C_{\mathrm{s}}=0.4 \mu \mathrm{M}\right)$, there was a linear relationship between the $\mathrm{P}-\mathrm{PO}_{4}$ concentration and growth rate:

$$
\begin{gathered}
\mu=\frac{C}{C_{\mathrm{s}}} \mu_{\max } \quad C \leq C_{\mathrm{s}} \\
\mu=\mu_{\max } \quad C>C_{\mathrm{s}}
\end{gathered}
$$

where $\mu=$ specific growth rate $\mathrm{d}^{-1}, \mu_{\max }=$ maximum specific growth rate (varies with light intensity and temperature) $\left(\mathrm{d}^{-1}\right)$ and $C=\mathrm{P}-\mathrm{PO}_{4}$ concentration $(\mu \mathrm{M})$. Our data could be fitted to such a saturation type kinetics model $\left(C_{\mathrm{s}} \approx 0.18 \mu \mathrm{M} ; \mu_{\max } \approx 0.33 \mathrm{~d}^{-1}\right)$ but the fit would not be good for values $\leq C_{\mathrm{s}}$; our data suggest that a curvilinear linear relationship would be more appropriate in the lower $\mathrm{P}_{-} \mathrm{PO}_{4}$ concentration range 0.0 to $0.18 \mu \mathrm{M}$.

Other experimental studies on P-limited growth support the concept of a saturation type model. The results of Thomas \& Dodson (1968) obtained from batch studies on P-limited growth of the diatom Chaetoceros exhibit a reasonable fit to a linear saturation type model with $C_{\mathrm{s}} \approx 0.22 \mu \mathrm{M}$. Thomas \& Dodson (1968) attempted to fit the hyperbolic Monod relation to their results but experienced some difficulty in doing so. Also, Fuhs et al. (1969) conclude that such a linear saturation model or a sharply bent asymptotic curve would be applicable to results that they obtained for Plimited growth of phytoplankton in their continuousflow culture experiments, but their experimental procedures did not allow them to quantify such a relationship.

\section{Implications for management of Lyngbya majuscula blooms in Moreton Bay}

The discharge of effluents from waste-water treatment plants (WWTPs) is the principal external source of $\mathrm{P}$ to Moreton Bay (Fig. 6) (Eyre \& McKee 2002). Many of the WWTPs discharge directly to the Bay, while others discharge to the estuarine sections (Fig. 1). In order to quantify the effects of the discharges on the water quality within the Bay, it is nec- 
essary to have information on the water quality outside the Bay, but this is not available. There is a limited amount of data for the eastern extremities of the Bay near to the entrance to Moreton Bay, and these data suggest an 'incoming-background' concentration for $\mathrm{P}_{-} \mathrm{PO}_{4}\left(C_{\mathrm{b}}\right)$ of $\sim 0.07 \mu \mathrm{M}$ (EHMP 2001). It is noted that the Bay waters would influence these waters, and therefore the true 'incoming-background' concentration could be somewhat less than this value; further studies are required to establish a more reliable estimate of $C_{\mathrm{b}}$. Recent water quality data from within the Bay (Fig. 1) show that the concentration of $\mathrm{P}_{-} \mathrm{PO}_{4}$ is much greater than $C_{\mathrm{b}}$ over most of Moreton Bay. Modelling studies on the effects of the WWTP discharges on the Bay show that the elevated concentrations (i.e. $\geq C_{\mathrm{b}}$ ) of $\mathrm{P}-\mathrm{PO}_{4}$ within the Bay can be attributed largely, if not solely, to the WWTP discharges (McEwan et al. 1998, Bell et al. 2003). The results in Fig. 5 show that the growth rate of Lyngbya majuscula is extremely sensitive to small increases in concentration of $\mathrm{P}_{-} \mathrm{PO}_{4}$ above $C_{\mathrm{b}}$. Thus, the results suggest that, provided it can be verified that $C_{\mathrm{b}}$ is significantly less than $C_{\mathrm{S}}$, the $\mathrm{P}_{-} \mathrm{PO}_{4}$ discharges from the WWTPs are producing an accelerated growth regime for L. majuscula throughout most, if not all, of Moreton Bay. Indeed, it is noted that $\mathrm{P}_{-} \mathrm{PO}_{4}$ concentrations generally exceed $C_{\mathrm{s}}$ throughout most of the Bay, and consequently there is potential for $L$. majuscula to grow at its maximum rate throughout most of the Bay. Dennison et al. (1999), in dismissing the importance of $\mathrm{P}_{-} \mathrm{PO}_{4}$ in the formation of Lyngbya blooms in Moreton Bay, had suggested that $\mathrm{P}_{-} \mathrm{PO}_{4}$ concentrations were low throughout the Lyngbya-bloom region, whereas in fact they ranged from 0.2 to $0.4 \mu \mathrm{M}$ and averaged $0.28 \pm 0.02 \mu \mathrm{M}$ throughout the bloom period (Watkinson 2000), i.e. they were greater than $C_{\mathrm{s}}$ and therefore would have provided for a maximal growth environment. We

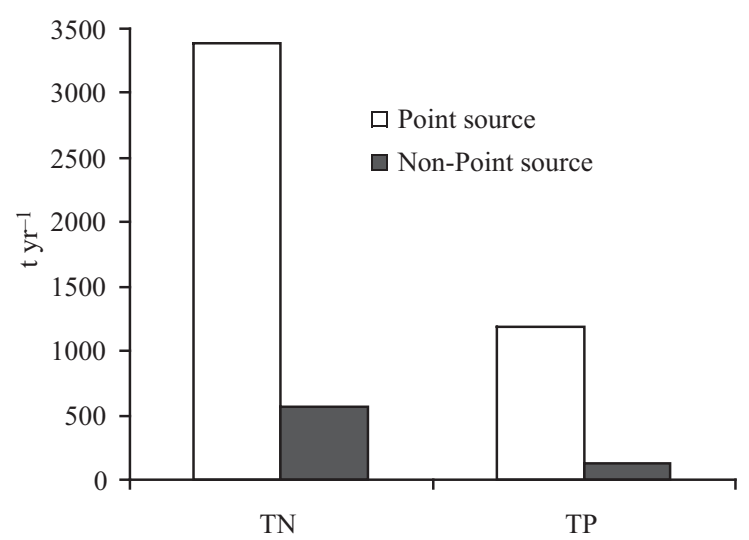

Fig. 6. Comparison of point source (i.e. WWTP discharges) and non-point source (i.e. run-off) loads of TN and TP to Moreton Bay (after Eyre \& McKee 2002) hypothesise that elevated $\mathrm{P}-\mathrm{PO}_{4}$ concentrations in the Bay are a primary contributor to the formation of blooms of L. majuscula within Moreton Bay and that, if it can be established that the WWTP discharges are the primary cause of the elevated $\mathrm{P}-\mathrm{PO}_{4}$ concentrations, then a reduction in the extent of these blooms will require a substantial reduction in the loads of $\mathrm{P}_{-} \mathrm{PO}_{4}$ from the WWTPs.

Results from some other studies had suggested that algal productivity in Moreton Bay is limited by the availability of $\mathrm{N}$, and based on these results, an extensive program on the reduction of $\mathrm{N}$ loads from WWTPs was recommended and is now being implemented (Dennison \& Abal 1999, Abal et al. 2001). It is important to note that the present emphasis of reducing only $\mathrm{N}$ loads from the WWTPs will reduce not only the concentrations of $\mathrm{N}$ in the Bay but will also reduce the $\mathrm{N}: \mathrm{P}$ ratio. This is important because it is now generally accepted that the conditions long recognised as promoting the growth of diazotrophs in freshwater systems, namely low $\mathrm{N}$ concentrations and a low $\mathrm{N}$ :P ratio, will also promote growth of diazotrophs in coastal waters (Niemi 1979, Sellner 1997). It is suggested that the control of bloom-forming diazotrophs such as Lyngbya majuscula in Moreton Bay will require consideration of both aspects, namely $\mathrm{N}$ concentrations and the N:P ratio. It is hypothesised that that the lower $\mathrm{N}$ concentrations and N:P ratios that will occur in many, if not most, regions of the Bay as a result of the $\mathrm{N}$-only removal strategy, will lead to an increase in the growth of $L$. majuscula and other diazotrophs in Moreton Bay.

\section{Conclusions}

Significant acetylene reduction, and consequently $\mathrm{N}_{2}$ fixation, was observed for Lyngbya majuscula during dark periods and only a minor amount occurred during light periods, which suggests that oxygenic photosynthesis and $\mathrm{N}_{2}$ fixation are incompatible processes for this species. The specific growth rate and $\mathrm{N}_{2}$ fixation rate of $L$. majuscula increased with $\mathrm{P}_{-} \mathrm{PO}_{4}$ concentration up to a maximum value and thereafter remained constant. The $\mathrm{P}_{-} \mathrm{PO}_{4}$ concentration corresponding to the maximum $\mathrm{N}_{2}$ fixation rate was $\sim 0.27 \mu \mathrm{M}$ and that corresponding to maximum growth rate was $\sim 0.18 \mu \mathrm{M}$. These values are denoted as the saturation values for $\mathrm{N}_{2}$ fixation and growth respectively. The concentrations of $\mathrm{P}_{-} \mathrm{PO}_{4}$ throughout Moreton Bay generally exceed these saturation values, and hence the growth of the bloom-forming L. majuscula is potentially maximised throughout much of the Bay by the elevated $\mathrm{P}_{-} \mathrm{PO}_{4}$ concentrations. Other studies suggest that the elevated $\mathrm{P}-\mathrm{PO}_{4}$ concentrations in the Bay can be largely attributed to discharges from WWTPs. 
Thus, it is proposed that the control of the growth of $L$. majuscula in Moreton Bay will require a significant reduction in the $\mathrm{P}$ load from the WWTP discharges. If the current strategy of $\mathrm{N}$ load reduction for these discharges to Moreton Bay is maintained in the absence of substantial P load reduction, it is hypothesised that the growth of L. majuscula and other diazotrophs in Moreton Bay will increase in the future.

\section{LITERATURE CITED}

Abal EG, Dennison WC, Greenfield PF (2001) Managing the Brisbane river and Moreton Bay: an integrated research/ management program to reduce impacts on an Australian estuary. Wat Sci Tech 43:57-70

Bell PRF, Elmetri I, Uwins P (1999) Nitrogen fixation of Trichodesmium spp. in the Great Barrier Reef Lagoon: relative importance of the 'new' nitrogen load. Mar Ecol Prog Ser 186:119-126

Bell PRF, McEwan J, Coombs S (2003) Finite element water quality model of the Moreton Bay system. In: Ozhan E (ed) Proc Medcoast 03: Sixth Int Conf Mediterranean Coastal Environment, 7-11 October 2003, Ravenna, Italy, p 1223-1234

Capone DG (1993) Determination of nitrogenase activity in aquatic samples using the acetylene reduction procedure. In: Kemp PF, Sherr BF, Sherr EB, Cole JJ (eds) Handbook of methods in aquatic microbial ecology. Lewis Publishers, Boca Raton, FL, p 621-631

Carpenter EJ, Price CC (1977) Nitrogen fixation, distribution, and production of Oscillatoria (Trichodesmium) spp. in the western Sargasso and Caribbean Seas. Limnol Oceanogr 22:60-72

Dennison WC, Abal EG (1999) Moreton Bay study: a scientific basis for healthy waterways campaign. South East Queensland Regional Water Quality Management Strategy. Brisbane City Council, Brisbane

Dennison WC, O'Neil JM, Duffy EJ, Oliver PE, Shaw GR (1999) Blooms of the cyanobacterium Lyngbya majuscula in coastal waters of Queensland, Australia. Bull Inst Oceanogr 19:501-506

Droop MR (1973) Some thoughts on nutrient limitation in algae. J Phycol 9:264-272

Drouet F (1968) Revision of the classification of the Oscillatoriaceae. Monograph 15, Academy of Natural Sciences of Philadelphia, Philadelphia

EHMP (2001) Ecological Health Monitoring Programme for Moreton Bay: water quality data for the year 2000-01. Environmental Protection Authority (EPA), Brisbane, Queensland

Eyre BD, McKee LJ (2002) Carbon, nitrogen, and phosphorus budgets for a shallow subtropical coastal embayment (Moreton Bay, Australia). Limnol Oceanogr 47: 1043-1055

Fuhs GW (1969) Phosphorus content and rate of growth in the diatoms Cyclotella nana and Thalassiosira fluviatilis. J Phycol 5:312-321

Goldman JC (1977) Steady state growth of phytoplankton in continuous culture: comparison of internal and external nutrient equations. J Phycol 13:251-258

Haas LW (1982) Improved epifluorescence microscopy for observing planktonic micro-organisms. Ann Inst Oceanogr 58:261-266

Howarth RW, Marino R, Lane J, Cole JJ (1988) Nitrogen fixa- tion in freshwater, estuarine and marine ecosystems. 1. Rates and importance. Limnol Oceanogr 33:669-687

Jones K (1990) Aerobic nitrogen fixation by Lyngbya spp., a marine tropical cyanobacterium. Br J Phycol 27:107-114

Kuffner Ilsa B, Paul BJ (2001) Effects of nitrate, phosphate and iron on the growth of macroalgae and benthic cyanobacteria from Cocos Lagoon, Guam. Mar Ecol Prog Ser 222: $63-72$

Lapointe BE, Clark MW (1992) Nutrient inputs from the watershed and coastal eutrophication in the Florida Keys. Estuaries 15:465-476

Lapointe BE, Matzie WR, Clark MW (1993) Phosphorus inputs and eutrophication on the Florida reef tract. Proc colloq, Global Aspects of Coral reefs, Health, Hazard and History. University of Miami, p 106-112

LMS (2003) Lyngbya Management Strategy-Moreton Bay Waterways and Catchment Partnership. Healthy Waterways, Brisbane City Council, Brisbane, Queensland

Lundgren P, Bauer K, Lugomela C, Soderback E, Bergman B (2003) Re-evaluation of the nitrogen fixation behaviour in the marine non-heterocystous cyanobacterium Lyngbya majuscula. J Phycol 39(2):310-314

Mague TH, Weare NM, Holm-Hansem O (1974) Nitrogen fixation in the north Pacific Ocean. Mar Biol 24:109-119

McEwan J, Gabric AJ, Bell PRF (1998) Water quality and phytoplankton dynamics in Moreton Bay, south-eastern Queensland. II. Mathematical modeling. Mar Freshw Res 49:227-239

Morel FMM, Rueter JG, Anderson DM, Guillard RR (1979) Aquil: a chemically defined phytoplankton culture medium for trace metal studies. J Phycol 15:135-141

Nagle DG, Paul VJ (1998) Chemical defense of a marine cyanobacterial bloom. J Exp Mar Biol Ecol 225:29-38

Niemi A (1979) Blue-green algal blooms and N:P ratio in the Baltic Sea. Acta Bot Fenn 110:57-61

Paerl HW (1990) Physiological ecology and regulation of $\mathrm{N}_{2}$ fixation in natural waters. Adv Microb Ecol 11:305-344

Paerl HW, Prufert LE, Ambrose WW (1991) Contemporaneous $\mathrm{N}_{2}$ fixation and oxygenic photosynthesis in the nonhetrocystous mat-forming cyanobacterium Lyngbya aestuarii. Appl Environ Microbiol 57:3086-3092

Parsons TR, Maita Y, Lalli CM (1984) A manual of chemical and biological methods for seawater analysis. Pergamon Press, Oxford

Phlips EJ, Inhat J, Conry M (1992) Nitrogen fixation by the benthic freshwater cyanobaterium Lyngbya wollei. Hydrobiologia 234:59-64

Porter JW, Meier OW (1992) Quantification of loss and change in Floridian reef coral populations. Am Zool 32:625-640

Postgate JR (1982) The fundamentals of nitrogen fixation. Cambridge University Press, Cambridge

Riley GA (1963) Theory of food-chain relations in the ocean. In: Hill MN (ed) The sea, ideas and observations on progress in the study of the seas. Interscience, New York, p 438-463

Sañudo-Wilhelmy SA, Kustka AB, Gobber CJ, Hutchins DA and 6 others (2001) Phosphorus limitation of nitrogen fixation by Trichodesmium in the central Atlantic Ocean. Nature 411:66-69

Sellner KG (1997) Physiology, ecology, and toxic properties of marine cyanobacteria blooms. Limnol Oceanogr 42: 1089-1104

Shannon K, Gross ED, Martin DF (1992) Variation of growth of Lyngbya majuscula as a function of salinity. Biomed Lett 47:29-33

Stal LJ, Krumbein WE (1985) Nitrogenase activity in the nonhetrocystous cyanobacterium Oscillatoria sp. Grown 
under alternating light-dark cycles. Arch Microbiol 143: $67-71$

Steele JH (1958) Plant production in the northern North Sea. Scottish Home Dept. Mar Res 7:17-24

Stewart WDP, Alexander GA (1971) Phosphorus availability and nitrogenase activity in aquatic blue-green algae. Freshw Biol 1:389-404

Thomas WH, Dodson AN (1968) Effects of phosphate concentration on cell division rates and yield of tropical oceanic diatom. Biol Bull 34:199-208

Editorial responsibility: Otto Kinne (Editor), Oldendorf/Luhe, Germany
Tyrrell $\mathrm{T}$ (1999) The relative influences of nitrogen and phosphorus on oceanic primary production. Nature 400: 525-531

Watkinson A (2000) Ecophysiology of the marine cyanobacterium, Lyngbya majuscula (Oscillatoriacea). BS thesis. University of Queensland, Brisbane

Zimmerman CF, Montgomery JR (1984) Effects of a decomposing drift algal mat on sediment pore water nutrient concentrations in a Florida seagrass bed. Mar Ecol Prog Ser 19:299-302

Submitted: November 20, 2003; Accepted: June 11, 2004 Proofs received from author(s): October 6, 2004 